\title{
Association between the artificial aging test and the natural storage of coffee seeds ${ }^{1}$
}

\author{
Tatiana Botelho Fantazzini², Sttela Dellyzete Veiga Franco da Rosa ${ }^{3 *}$, \\ Cristiane Carvalho Pereira ${ }^{2}$, Diego de Sousa Pereira ${ }^{2}$, Marcelo Ângelo Cirillo $^{4}$, \\ Paulo César Ossani ${ }^{4}$
}

\begin{abstract}
The accelerated aging test is recognized as an efficient method for evaluating the vigor of seed lots and for estimating their storage potential. Thus, this work aimed to evaluate the association between artificial aging and natural storage of coffee seeds, through the correlation factor analysis. Seeds of four cultivars of Coffea arabica L. (Catuai Amarelo, Arara, Catiguá, and Mundo Novo) and one of Coffea canephora Pierre (Apoatã) were used. Part of the newly-harvested seeds were aged in a growth chamber under controlled temperature and relative humidity conditions $\left(42{ }^{\circ} \mathrm{C}\right.$ and $\left.100 \% \mathrm{RH}\right)$ for periods of $0,4,6,8$, and 10 days. The other part of the seeds was stored in tri-wall paper packaging for a period of 2, 4, and 6 months in a non-climate-controlled environment. Artificial aging allows predictions on the storage potential of coffee seeds, although the artificial aging periods depend on the cultivars.
\end{abstract}

Index terms: vigor test, Coffea cultivars, germination.

\section{Associação do teste de envelhecimento artificial com o armazenamento natural de sementes de café}

\begin{abstract}
RESUMO - O teste de envelhecimento artificial tem se destacado como um método eficiente para avaliar o vigor de lotes de sementes e para estimar o potencial de armazenamento dos mesmos. Assim, este trabalho teve o objetivo de avaliar a associação entre o envelhecimento artificial e o armazenamento natural de sementes de café, por meio da correlação via análise de fatores. Foram utilizadas sementes de quatro cultivares de Coffea arabica L. e uma de Coffea canephora Pierre. Parte das sementes recém-colhidas foi envelhecida em câmara de crescimento do tipo BOD sob condições controladas de temperatura e umidade relativa ( $42{ }^{\circ} \mathrm{C}$ e $100 \%$ UR) por períodos de $0,4,6,8$ e 10 dias. A outra parte das sementes foi armazenada em embalagens de papel trifoliado por um período de 2, 4 e 6 meses em armazém, em ambiente não controlado. O envelhecimento artificial prediz a armazenabilidade de sementes de café, sendo os tempos de envelhecimento artificial dependentes das cultivares.
\end{abstract}

Termos para indexação: teste de vigor, cultivares de Coffea, germinação.

\section{Introduction}

Seeds of the genus Coffea present a quite limited conservation, due to their intermediate and recalcitrant characteristics regarding desiccation tolerance and storage behavior (Ellis et al., 1990; Abreu et al., 2014; Coelho et al., 2015). Among several factors that affect the quality of coffee seeds, moisture content, drying and storage conditions are considered to be the most important ones,

${ }^{1}$ Submitted on 11/21/2017. Accepted for publication on 03/05/2018

${ }^{2}$ Departamento de Agricultura, Universidade Federal de Lavras - UFLA, 37.200-000 - Lavras, MG, Brasil.

${ }^{3}$ Embrapa Café, Parque Estação Biológica PqEB, 70770-90 - Brasília, DF, Brasil. especially because of the sensitivity of these seeds to desiccation. Due to the intermediate behavior of Coffea arabica $\mathrm{L}$. and to the greater tendency to recalcitrance of Coffea canephora Pierre, seeds of these species show low longevity, which is one of the biggest difficulties faced by producers and seed technologists, since the storage conditions may cause irreversible damages to seed viability (Vieira et al., 2007).

In most crops propagated by seeds, the harvest season

${ }^{4}$ Departamento de Estatística, Universidade Federal de Lavras - UFLA, 37.200-000 - Lavras, MG, Brasil.

*Corresponding author<stella.rosa@embrapa.br> 
does not always coincide with the proper period for sowing. For that reason, seeds are stored to maintain their physiological quality (Souza et al., 2007). Thus, storage is a safe and economical form of preserving plant genetic diversity, in addition to controlling the deterioration, a natural and irreversible process of physical destabilization and loss of the physiological capacity (González et al., 2012).

Araújo et al. (2008) remark that the conservation of the quality of coffee seeds during storage is one of the greatest challenges faced by seeds producers, once coffee seeds rapidly lose their viability and do not maintain their germination capacity at satisfactory levels for periods longer than six months after harvest. Therefore, it is highly desirable that coffee seeds can be safely stored, either to optimize the production of seedlings or to guarantee their medium- and long-term longevity. However, researches related to seed storage in general face limitations, such as the time required to perform these studies. Thus, the artificial aging test can predict the deterioration level of the seeds throughout the storage.

The artificial aging test was initially developed by Delouche (1965) in order to estimate the storage potential of clover and fescue seeds (Ataíde et al., 2012). However, it is widely used to evaluate seedling performance in field, and to make distinction on the physiological quality of seed lots with similar emergence behavior (Miloševic et al., 2010). This is considered a method that simulates stress conditions, generating high respiration rates and consumption of the reserves, thus causing degenerative changes in seed metabolism (Moraes et al., 2016).

The principle of this test is to promote a fast deterioration of seeds, by exposing them to high temperature and relative air humidity, conditions that intensify the aging process (Marcos-Filho, 2015). So, seed lots with high vigor will maintain the viability or be little affected when submitted to stress, whereas those with low vigor will have their viability reduced, making possible to stablish differences in the physiological potential of the lots (Miloševic et al., 2010; Pereira et al., 2012; Tunes et al., 2011).

The artificial aging has been often used in quality control programs adopted by seed companies, because it gives, in just a few days, reliable information on the storage potential of the lots produced (Silva et al., 2010). Camargo et al. (2000), Freitas et al. (2006) and Santos and Paula (2007) affirmed that there is a correlation between natural and artificial aging of seeds of Eucalyptus grandis, Gossypium hirsutum and Sebastiania commersoniana. Also, the mechanisms that promote the deterioration are the same in both situations, varying only at the speed that they occur.

Although the test is successfully used to assess the vigor in several species, especially to detect differences in the physiological potential of lots that present similar germination, and to estimate the storage potential of seeds, there is still little information on its usage in coffee seeds.

Thus, the use of tests that provide an estimate of seed performance during storage is an important aspect to be considered in a seed production program. Therefore, this work aimed to evaluate the association between artificial aging and natural storage of coffee seeds through factor analysis correlation.

\section{Material and Methods}

The experiment was carried out at the Central Laboratory of Seeds, Department of Agriculture, Universidade Federal de Lavras (UFLA), city of Lavras, state of Minas Gerais (MG), Brazil. Seeds of four Coffea arabica L. cultivars (Catuaí Amarelo, Arara, Catiguá and Mundo Novo) and one Coffea canephora Pierre cultivar (Apoatã), from the 2014/2015 crop year were used. The seeds came from the experimental farm Procafé, city of Varginha, located in the south region of Minas Gerais (21 ${ }^{\circ} 33^{\prime}$ 'S latitude, $45^{\circ} 25^{\prime}$ W Gr longitude, and $980 \mathrm{~m}$ altitude), where the climate is tropical highland (Cwb), according to Köppen's classification.

Coffee fruits were selectively harvested at the cherry stage, from medium branches and at the medium part of the plants. After harvested, the fruits were once again selected to assure maturation uniformity, and then mechanically peeled. The seeds were pulped by fermentation in water for 24 hours, and then they were shade-dried until $12 \%$ moisture content, for Coffea arabica L. seeds, or $17 \%$, for Coffea canephora Pierre seeds.

Part of the seeds was submitted to the artificial aging test in a BOD chamber under controlled temperature and relative humidity conditions $\left(42{ }^{\circ} \mathrm{C}\right.$ and $\left.100 \% \mathrm{RH}\right)$ for periods of 0,4 , 6,8 and 10 days. The other part was stored in tri-wall paper bags for periods of 2, 4 and 6 months, in an environment without temperature nor relative humidity control. After each period of artificial aging and natural storage, the moisture content of the seeds was determined, and their physiological quality was assessed through the germination test.

\section{Moisture content}

It was determined before and after the artificial aging periods by the oven method, at $105^{\circ} \mathrm{C}$ for 24 hours. The results were expressed as percentage in wet basis, according to the Regras para Análise de Sementes - RAS (Brasil, 2009).

\section{Germination test}

It was carried out on germitest paper moistened with 
distilled water in the proportion of 2.5 times the dry paper weight. Four replications of 50 seeds each were placed in a germinator set at $30{ }^{\circ} \mathrm{C}$, under light. Normal seedling counts were performed 30 days after sowing (Brasil, 2009), and the results were expressed as percentage of normal seedlings.

\section{Statistics procedures}

The experimental design was completely randomized, with four replications, five artificial aging periods $(0,4,6$, 8 and 10 days), and three natural storage periods (2, 4 and 6 months) for each cultivar. Analysis of variance of the data was performed with the software Sisvar ${ }^{\circledR}$ (Ferreira, 2011), and the results were presented in tables of mean values, compared by the Scott-Knott test at 5\% probability.

A simple correlation analysis of the data was also performed with the software Assistat, version 7.5 Beta. For the study of the joint effect of the variation factors, artificial aging and natural storage periods of the coffee cultivars, the multivariate factor analysis method was applied through the development of plots with the software R, MVar.pt pack, version 1.9.5 (Ossani and Cirillo, 2016), considering the mean germination values. This type of analysis allows to estimate the factor loadings, indicating possible correlations (shown in the biplot graphs) and their communalities, which are interpreted as the proportion of variance of a variable (periods) that is shared by both factors.

\section{Results and Discussion}

The seeds of Coffea arabica L. cultivars presented similar moisture contents in each artificial aging period, reaching the moisture levels required to promote the artificial aging (Table 1). The Coffea canephora Pierre cultivar showed higher initial moisture content, since it is more sensible to desiccation and does not tolerate greater moisture reductions, but the seeds also reached moisture contents in which the deterioration occurred, possibly because of oxidative damages and malfunctioning of protection mechanisms (Dussert et al., 2012; Marcos-Filho, 2015).
During the artificial aging, seeds absorbed water and reached moisture content values above $40 \%$ after 10 days. According to Carvalho and Nakagawa (2012), increases in moisture content favor the rise of seed temperature due to the respiration processes and to the greater microorganism activity. Thus, the more the seeds were exposed to the artificial aging, the higher their moisture content became, leading to a rise in temperature $\left(42^{\circ} \mathrm{C}\right)$. This results in a greater deterioration of the seeds, in comparison to the non-aged ones.

In all cultivars, a reduction in seed germination potential was observed throughout the artificial aging (Table 2). This negative effect was more pronounced up from 8 days of seed exposure to high temperature and high relative humidity. As for the seeds that were stored under uncontrolled conditions, they lost quality after 4 months of storage.

The greatest reduction in physiological quality occurred in seeds of the Apoatã cultivar after 8 days of artificial aging, and it became even more intense after 4 months of natural storage. This greater loss of quality is related to the fact that the cultivar belongs to the species Coffea canephora, which has more recalcitrant seeds, as related by Rosa et al. (2005) and Vieira et al. (2007).

The results of the simple linear correlation analysis (Table 3) showed a significant correlation between the period of artificial aging of 4 days, and the natural storage for 2 months for the Catuai Amarelo cultivar. In this cultivar, there were negative correlations between the artificial aging period of 8 days and the natural storage for 4 months, and between the artificial aging period of 10 days and the natural storage for 4 months.

For the Arara, Mundo Novo and Apoatã cultivars, there was no significant correlation between the germination results after the different artificial aging periods and natural storage. The cultivar Catiguá, in its turn, showed significant negative correlations between the artificial aging period of 4 days and the natural storage for 4 months, and between the artificial aging of 6 days and the natural storage for 4 months. It should be emphasized that the variables can be grouped, once they express strong, moderate or weak correlations between the

Table 1. Mean values of moisture content of coffee seeds before and after each artificial aging period.

\begin{tabular}{cccccc}
\hline \multirow{2}{*}{ Cultivars } & \multicolumn{5}{c}{ Periods of artificial accelerated aging (days) } \\
\cline { 2 - 6 } & 0 & 4 & 6 & 8 & 10 \\
\hline Catuaí Amarelo & 13.0 & 28.7 & 31.9 & 36.9 & 42.8 \\
Arara & 13.2 & 27.8 & 32.7 & 34.4 & 40.6 \\
Catiguá & 12.9 & 30.9 & 35.8 & 38.7 & 42.3 \\
Mundo Novo & 12.8 & 32.2 & 36.9 & 38.4 & 41.5 \\
Apoatã (C. canephora) & 17.6 & 30.9 & 34.1 & 36.3 & 40.0 \\
\hline
\end{tabular}


Table 2. Mean values of germination percentage of coffee cultivars submitted to different periods of accelerated aging and natural storage.

\begin{tabular}{cccccc}
\hline & \multicolumn{5}{c}{ Cultivars } \\
\cline { 2 - 6 } Treatments & \multicolumn{5}{c}{ Germination (\%) } \\
\cline { 2 - 5 } & Catuaí & Arara & Catiguá & Mundo Novo & Apoatã (Coffea canephora) \\
\hline 0 days & $84 \mathrm{~A}$ & $64 \mathrm{~B}$ & $79 \mathrm{~A}$ & $80 \mathrm{~A}$ & $88 \mathrm{~A}$ \\
4 days & $79 \mathrm{~A}$ & $60 \mathrm{~B}$ & $63 \mathrm{~B}$ & $75 \mathrm{~A}$ & $52 \mathrm{C}$ \\
6 days & $81 \mathrm{~A}$ & $62 \mathrm{~B}$ & $66 \mathrm{~B}$ & $73 \mathrm{~A}$ & $40 \mathrm{D}$ \\
8 days & $68 \mathrm{~B}$ & $52 \mathrm{C}$ & $60 \mathrm{~B}$ & $48 \mathrm{~B}$ & $4.0 \mathrm{E}$ \\
10 days & $65 \mathrm{~B}$ & $45 \mathrm{C}$ & $36 \mathrm{C}$ & $46 \mathrm{~B}$ & $68 \mathrm{~B}$ \\
2 months & $82 \mathrm{~A}$ & $75 \mathrm{~A}$ & $75 \mathrm{~A}$ & $81 \mathrm{~A}$ & $1.0 \mathrm{E}$ \\
4 months & $24 \mathrm{C}$ & $43 \mathrm{C}$ & $26 \mathrm{C}$ & $11 \mathrm{C}$ & $0.0 \mathrm{E}$ \\
6 months & $0.0 \mathrm{D}$ & $10 \mathrm{D}$ & $1.0 \mathrm{D}$ & $0.0 \mathrm{D}$ & 13.96 \\
\hline CV $(\%)$ & & & & \\
\hline
\end{tabular}

* Means followed by the same uppercase letter in the column do not differ statistically from each other at 5\% significance, according to the Scott-Knott test.

Table 3. Linear correlation coefficients between the artificial aging periods (E) of 0, 4, 6, 8 and 10 days, and the natural storage periods (EN) of 2, 4 and 6 months, for the germination values of the coffee cultivar seeds.

\begin{tabular}{lccccc}
\hline & \multicolumn{4}{c}{ Coffea cultivars } \\
\cline { 2 - 5 } & Catuaí & Arara & Catiguá & Mundo Novo & Apoatã (Coffea canephora) \\
\hline E0 x EN2 & 0.1667 & -0.4115 & -0.5863 & -0.1826 & 0.5774 \\
E0 x EN4 & -0.6420 & 0.3177 & 0.4973 & -0.5717 & -0.9045 \\
E0 x EN6 & 0.0000 & 0.3273 & 0.2075 & 0.0000 & 0.0000 \\
E4 x EN2 & $0.9528^{*}$ & -0.1641 & 0.0434 & 0.7502 & 0.0000 \\
E4 x EN4 & -0.0856 & -0.3042 & $-0.9633^{*}$ & 0.4057 & -0.4924 \\
E4 x EN6 & 0.0000 & -0.4352 & -0.5103 & 0.0000 & 0.0000 \\
E6 x EN2 & -0.9201 & 0.0442 & -0.1497 & 0.2582 & -0.4714 \\
E6 x EN4 & 0.2215 & -0.2046 & $-0.9925^{* *}$ & 0.0269 & 0.7385 \\
E6 xEN6 & 0.0000 & -0.3746 & -0.1741 & 0.0000 & 0.0000 \\
E8 x EN2 & -0.2887 & 0.6172 & 0.8291 & 0.6000 & 0.7303 \\
E8 x EN4 & $-0.9885^{*}$ & 0.8897 & -0.4781 & 0.9393 & -0.7628 \\
E8 x EN6 & 0.0000 & 0.7638 & -0.6428 & 0.0000 & 0.0000 \\
E10 x EN2 & -0.3282 & -0.3333 & 0.3928 & -0.2582 & -0.8165 \\
E10 x EN4 & $-0.9747^{*}$ & -0.3775 & -0.5285 & -0.7276 & 0.4264 \\
E10 x EN6 & 0.0000 & -0.4714 & 0.0000 & 0.0000 & 0.0000 \\
\hline
\end{tabular}

** significant at $1 \%$ probability

* significant at $5 \%$ probability

artificial aging and the natural storage periods. Thus, in order to explain these correlations in two latent variables, the factor analysis should be applied.

The factor analysis is a set of statistic methods that, in some situations, allows to explain the behavior of a relatively large amount of observed variables in terms of a relatively small number of latent variables or factors. This analysis can be understood as an exploratory technique, designed to summarize the information contained in a set of variables within a group of factors, so the number of factors is considerably smaller than the number of observed variables (Rezende et al., 2007).

In order to validate the factorial analysis, the percentage of data variation to be explained by the two new factors should be relatively high. The results in Table 4 corroborate with this premise, and they represent the adjustment of the first two factors for the data of different artificial aging and the natural storage periods, for each coffee cultivar separately, and also for all cultivars together. The result indicates that at least $83.28 \%$ of the data set variation are explained by the first two factors for each coffee cultivar analyzed separately. When the analysis is performed in all cultivars together, the two factors explain $75.67 \%$ of the total variance, which evidences that these analyses can be explained in a two-dimensional space (Table 4). 
Table 4. Estimates of the variance, percentage of variance and cumulative variance of the first two factors obtained from the cultivars Catuaí Amarelo, Arara, Catiguá, Mundo Novo and Apoatã (C. canephora) and from all cultivars together.

\begin{tabular}{|c|c|c|c|}
\hline Cultivars & Number of factors & Variance & Cumulative variance (\%) \\
\hline \multirow{3}{*}{ Catuaí Amarelo } & 1 & 4.4333 & 55.42 \\
\hline & 2 & 2.3298 & 29.12 \\
\hline & Total & 6.7631 & 84.54 \\
\hline \multirow{3}{*}{ Arara } & 1 & 4.1064 & 51.33 \\
\hline & 2 & 2.5562 & 31.95 \\
\hline & Total & 6.6626 & 83.28 \\
\hline \multirow{3}{*}{ Catiguá } & 1 & 3.9066 & 48.83 \\
\hline & 2 & 2.7839 & 34.80 \\
\hline & Total & 6.6905 & 83.63 \\
\hline \multirow{3}{*}{ Mundo Novo } & 1 & 4.5326 & 56.66 \\
\hline & 2 & 2.6350 & 32.94 \\
\hline & Total & 7.1676 & 89.60 \\
\hline \multirow{3}{*}{ Apoatã (C. canephora) } & 1 & 5.1286 & 64.11 \\
\hline & 2 & 2.4798 & 31.00 \\
\hline & Total & 7.6084 & 95.11 \\
\hline \multirow{3}{*}{ All cultivars together } & 1 & 3.5937 & 44.92 \\
\hline & 2 & 2.4601 & 30.75 \\
\hline & Total & 6.0538 & 75.67 \\
\hline
\end{tabular}

Table 5 shows the communalities and the estimate factor loading values for Catuaí Amarelo, Arara, Catiguá, Mundo Novo, Apoatã (C. canephora) cultivars, and for all cultivars together. Communalities are indices attributed to the original variables that express, as percentage, how much of the variability in each variable is explained by the factor analysis model. It can be noted that there is an agreement between the greatest communalities observed in the artificial aging periods and the storage periods. In general, the greater the communality observed in a variable, the better the variable is explained by the factor. Thus, these measurements can be optionally used to name or characterize a factor in order to simplify its interpretation.

As for the factor loadings, they can be interpreted as a measure of the variable correlation with the factors, that is, how much each variable is associated with each factor.

The graphs shown in Figure 1, corresponding to the biplots of the response variables for Catuai Amarelo, Arara, Catiguá, Mundo Novo cultivars, were elaborated considering the first two factors, in order to identify the correlated variables.

In the biplot graph (Figure 1), the vectors represent the studied treatments, and the angle formed corresponds to the correlation between them. The smaller the angle formed by the vectors in relation to the factors, the greater the correlation between the treatments. Therefore, it was possible to confirm an existing correlation between the scores of the artificial aging and the natural storage periods.

For the Catuai Amarelo (Figure 1a) e Arara (Figure 1b) cultivars, the vectors representing 10 days of artificial aging and 4 months of natural storage formed smaller angles between them, which indicates correlation. This correlation is greater in the Arara cultivar, due to the closer distance of the vectors in the biplot graphs. For the Arara cultivar, the periods of 4 and 8 days of artificial aging present correlation with the natural storage for 4 months.

In Figure 1c, the vectors corresponding to 6 days of artificial aging and 2 months of natural storage for the Catiguá cultivar formed a small angle, indicating that seeds artificially aged for 6 days showed the same physiological deterioration level as seeds stored for up to 2 months, according to the high correlation between these periods. In the Mundo Novo cultivar (Figure 1d), the seeds artificially aged for 6 days presented a strong correlation with those naturally stored for 4 months, evidenced by the small angle between the vectors. The same correlation can be observed between the seeds artificially aged for 8 days and those stored for 2 months.

Figure 2 shows the scores of artificial aging and storage periods for the Apoatã (C. canephora) cultivar. It can be observed that the angle formed between the vectors of 4,8 and 10 days of artificial aging and the one of 2 month storage are very close, which indicates high correlation between them.

The biplot graphs in Figure 3 represent the analyses of the cultivars altogether. They allow to observe a high correlation between the periods of 4, 6, 8 and 10 days of artificial aging and 2 months of natural storage, indicating similar deterioration levels of the seeds.

In general, according to the results of multivariate factor analysis, the artificial aging periods of 10 and 6 days for Catuai Amarelo, Arara and Mundo Novo cultivar seeds caused a deterioration equivalent to that of 4 months of natural storage, given the correlation of the factors. 
Table 5. Factor loading values of the first two factors and communalities obtained for the Catuai Amarelo, Arara, Catiguá, Mundo Novo and Apoatã cultivars, in separate, and for all cultivars together, when submitted to different artificial aging periods (0, 4, 6,8 and 10 days) and different natural storage periods (2, 4 and 6 months).

\begin{tabular}{|c|c|c|c|c|c|c|c|c|}
\hline \multirow{3}{*}{ Factor } & \multicolumn{8}{|c|}{ Catuaí Amarelo cultivar } \\
\hline & \multicolumn{5}{|c|}{ Artificial aging periods } & \multicolumn{3}{|c|}{ Natural storage periods } \\
\hline & 0 days & 4 days & 6 days & 8 days & 10 days & 2 months & 4 months & 6 months \\
\hline 1 & 0.920 & -0.849 & 0.277 & -0.837 & -0.595 & 0.959 & 0.329 & 0.842 \\
\hline 2 & -0.378 & 0.307 & -0.925 & -0.513 & 0.618 & 0.285 & 0.594 & 0.398 \\
\hline Communality & 0.989 & 0.815 & 0.933 & 0.964 & 0.735 & 1.000 & 0.461 & 0.867 \\
\hline \multirow{3}{*}{ Factor } & \multicolumn{8}{|c|}{ Arara cultivar } \\
\hline & \multicolumn{5}{|c|}{ Artificial aging periods } & \multicolumn{3}{|c|}{ Natural storage periods } \\
\hline & 0 days & 4 days & 6 days & 8 days & 10 days & 2 months & 4 months & 6 months \\
\hline 1 & -0.358 & -0.806 & -0.145 & -0.723 & -0.983 & 0.667 & -0.930 & 0.713 \\
\hline 2 & 0.893 & -0.592 & 0.921 & 0.076 & -0.007 & 0.543 & -0.026 & -0.508 \\
\hline Communality & 0.925 & 0.999 & 0.869 & 0.529 & 0.967 & 0.740 & 0.866 & 0.767 \\
\hline \multirow{3}{*}{ Factor } & \multicolumn{8}{|c|}{ Catiguá cultivar } \\
\hline & \multicolumn{5}{|c|}{ Artificial aging periods } & \multicolumn{3}{|c|}{ Natural storage periods } \\
\hline & 0 days & 4 days & 6 days & 8 days & 10 days & 2 months & 4 months & 6 months \\
\hline 1 & 0.397 & -0.686 & -0.068 & -0.935 & -0.938 & 0.460 & 0.963 & 0.618 \\
\hline 2 & -0.848 & -0.549 & -0.984 & -0.339 & 0.073 & -0.758 & -0.177 & 0.265 \\
\hline Communality & 0.877 & 0.772 & 0.972 & 0.990 & 0.884 & 0.785 & 0.958 & 0.452 \\
\hline \multirow{3}{*}{ Factor } & \multicolumn{8}{|c|}{ Mundo Novo cultivar } \\
\hline & \multicolumn{5}{|c|}{ Artificial aging periods } & \multicolumn{3}{|c|}{ Natural storage periods } \\
\hline & 0 days & 4 days & 6 days & 8 days & 10 days & 2 months & 4 months & 6 months \\
\hline 1 & -0.943 & -0.878 & -0.107 & 0.902 & -0.882 & 0.741 & -0.287 & -0.798 \\
\hline 2 & -0.182 & 0.326 & -0.986 & -0.340 & 0.365 & -0.153 & -0.943 & -0.601 \\
\hline Communality & 0.923 & 0.877 & 0.984 & 0.929 & 0.912 & 0.573 & 0.972 & 0.999 \\
\hline \multirow{3}{*}{ Factor } & \multicolumn{8}{|c|}{ Apoatã (C. canephora) cultivar } \\
\hline & \multicolumn{5}{|c|}{ Artificial aging periods } & \multicolumn{3}{|c|}{ Natural storage periods } \\
\hline & 0 days & 4 days & 6 days & 8 days & 10 days & 2 months & 4 months & 6 months \\
\hline 1 & -0.147 & 0.882 & -0.737 & 0.955 & 0.850 & 0.991 & -0.578 & -0.914 \\
\hline 2 & 0.987 & -0.466 & 0.672 & 0.124 & 0.392 & 0.031 & -0.809 & 0.110 \\
\hline Communality & 0.996 & 0.995 & 0.994 & 0.927 & 0.877 & 0.983 & 0.989 & 0.847 \\
\hline \multirow{3}{*}{ Factor } & \multicolumn{8}{|c|}{ All cultivars together } \\
\hline & \multicolumn{5}{|c|}{ Artificial aging periods } & \multicolumn{3}{|c|}{ Natural storage periods } \\
\hline & 0 days & 4 days & 6 days & 8 days & 10 days & 2 months & 4 months & 6 months \\
\hline 1 & 0.246 & -0.774 & -0.823 & -0.774 & -0.934 & -0.728 & -0.499 & -0.078 \\
\hline 2 & -0.802 & -0.46 & -0.283 & -0.036 & 0.044 & -0.136 & 0.811 & 0.919 \\
\hline Communality & 0.704 & 0.811 & 0.758 & 0.601 & 0.874 & 0.548 & 0.907 & 0.851 \\
\hline
\end{tabular}

*Coefficient of correlation: $<0.3$ (weak correlation); $0.3 \leq \mathrm{CS}<0.5$ (low correlation); $0.5 \leq \mathrm{CS}<0.7$ (moderate correlation); $0.7 \leq \mathrm{CS}<0.9$ (high correlation); $0.9 \leq \mathrm{CS}<1.0$ (strong correlation).

As stated by Ataíde et al. (2012), the artificial aging test was developed to predict the storage potential of lots of clover and fescue. So, this test has been used to investigate the physiological mechanisms involved in the aging process during storage (Sung and Jeng, 1994).

However, there is no consensus as to whether the events resulting from the artificial aging are similar to those that naturally occur in seeds (Borges et al., 2002;
Fanan et al., 2006). According to Silva et al. (2010), the artificial aging test can act as a tool in programs of genetic improvement, to select cultivars with storage potential and capable of developing under temperature and high relative humidity conditions.

When studying the behavior of Melanoxylon brauna seeds submitted to natural and artificial aging, Corte et al. (2010) observed that the artificial aging at $40{ }^{\circ} \mathrm{C}$ for 
a)

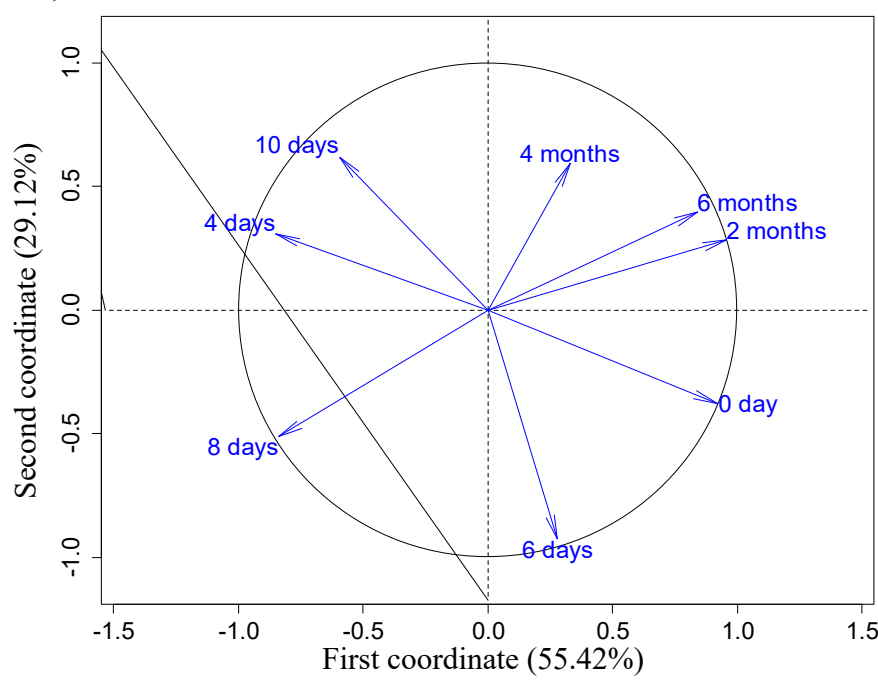

c)

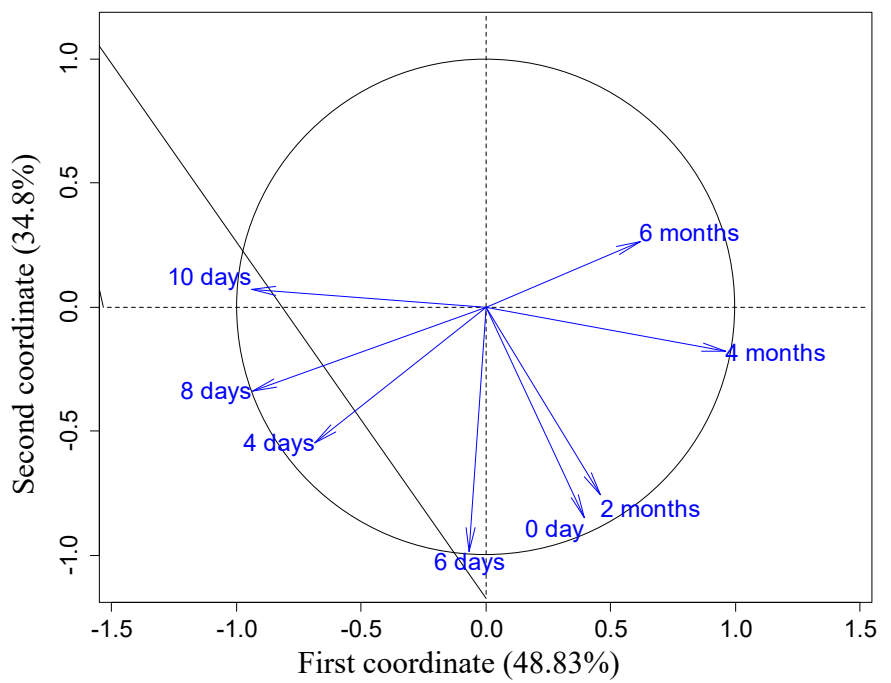

b)

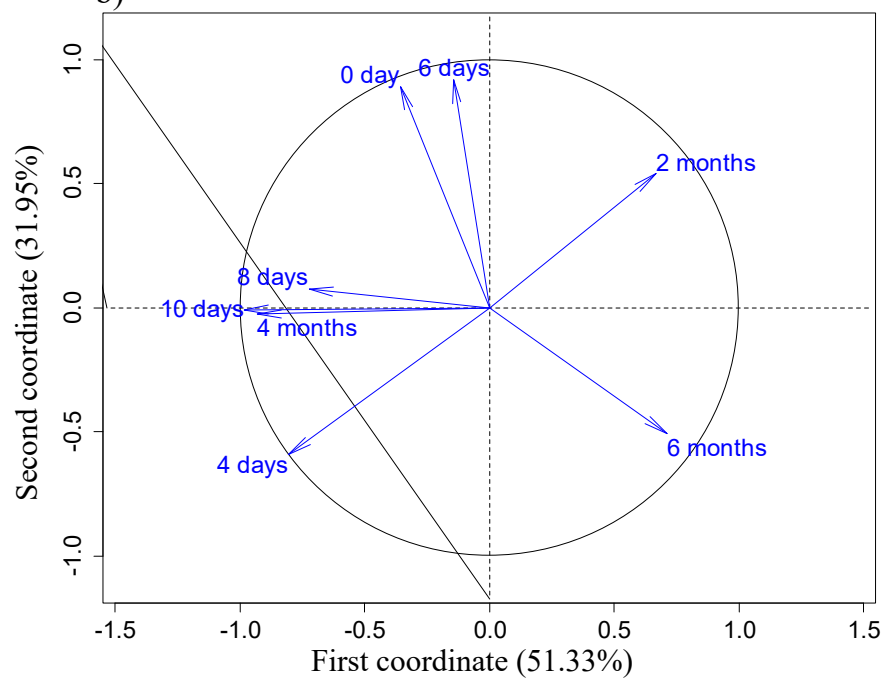

d)

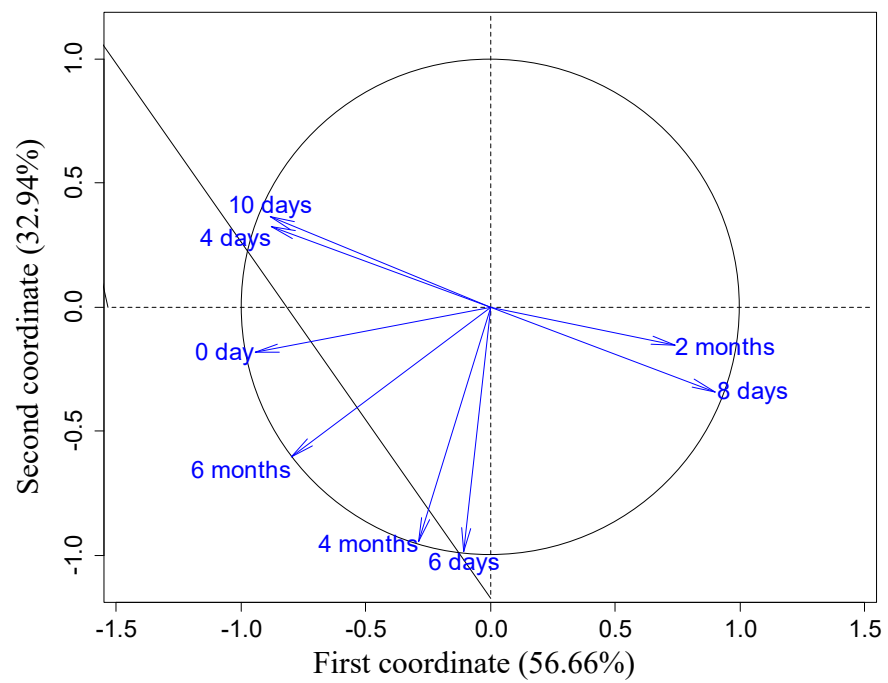

Figure 1. Biplot graphs of the scores obtained from the artificial aging periods $(0,4,6,8$ and 10 days $)$ and the natural storage periods (2, 4 and 6 months) of Catuai Amarelo (a), Arara (b), Catiguá (c) and Mundo Novo (d) cultivars, for the seed germination results.

96 hours simulated the same germination behavior of the seeds stored for 12 months in cold chamber at $20^{\circ} \mathrm{C}$. Garcia et al. (2014) worked with Araucaria angustifolia, another recalcitrant species, and verified that the viability of seeds submitted to the artificial aging test was similar to those naturally aged after 60 days of storage in an uncontrolled environment. Balešević-Tubić et al. (2010) and Freitas et al. (2006) stated that the artificial aging test is efficient in providing information on the storage capacity of soybean, sunflower and cotton seeds. Similarly, Shibata et al. (2012), studying the behavior of Tabebuia alba seeds, a species with behavior similar to the coffee plant, verified that the artificial aging simulated the natural storage of the seeds.

Similar results were obtained in the present study with coffee seeds from different cultivars, in which the artificial aging periods that predict the natural storage periods (confirmed by the correlations from the multivariate factor analysis) were variable among the cultivars. Therefore, it was possible to establish artificial aging periods capable of predicting or simulating the natural storage for each cultivar. However, it is worth mentioning that the artificial aging periods from 6 to 10 days at $42{ }^{\circ} \mathrm{C}$ and $100 \%$ relative humidity seem to be too long, which suggests that other environmental conditions inside the aging chamber should 
be investigated, in order to reduce the duration of the test, and to allow the simulation of coffee seeds deterioration during the natural storage.

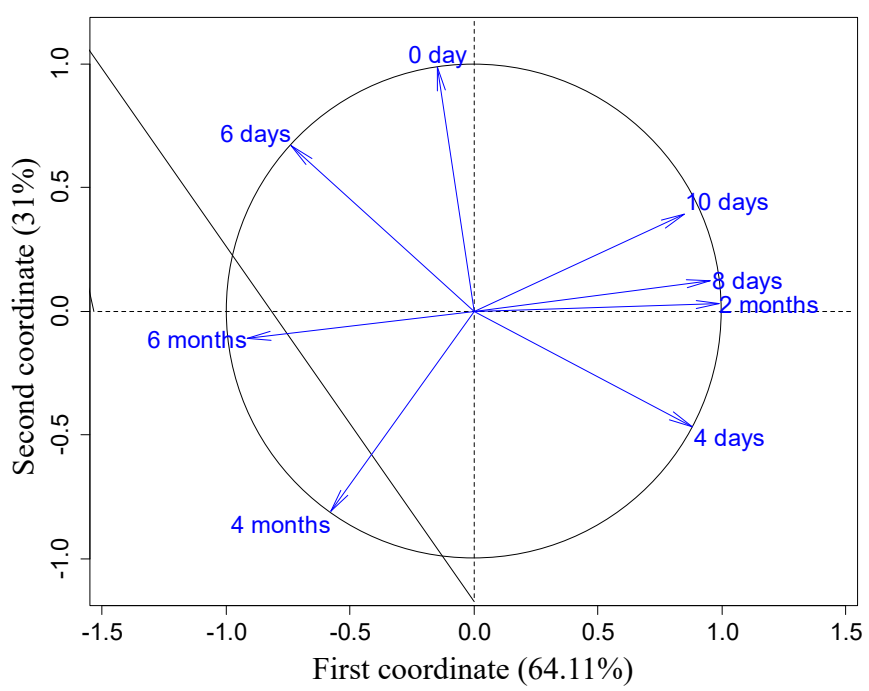

Figure 2. Biplot graph of the scores obtained from the artificial aging periods ( $0,4,6,8$ and 10 days) and the natural storage periods (2, 4 and 6 months) of Apoatã (C. canephora) cultivar, for the seed germination results.

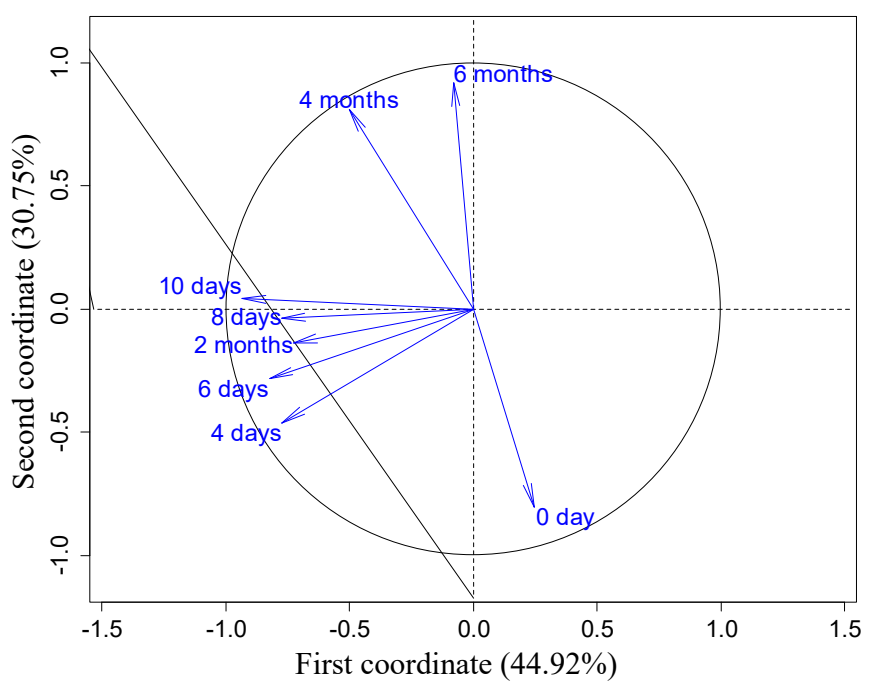

Figure 3. Biplot graph of the scores obtained from the artificial aging periods ( $0,4,6,8$ and 10 days) and the natural storage periods (2, 4 and 6 months) of all cultivars together, for the seed germination results.

\section{Conclusions}

The artificial aging predicts the storage capacity of coffee seeds, and the duration depends on the cultivars.

\section{References}

ABREU, L.A.S.; VEIGA, A.D.; VON PINHO, E.V.R.; MONTEIRO, F.F.; ROSA, S.D.V.F. Behavior of coffee seeds to desiccation tolerance and storage. Journal of Seed Science, v.36, n.4, p.399-406, 2014. http://www.scielo.br/scielo.php?script=sci arttext\&pid=S2317-15372014000400003

ARAÚJO, R.F.;ARAUJO,E.F.; CECON,P.R; SOFIATTI, V.Conservação de sementes de café (Coffea arabica L.) despolpado e não despolpado. Revista Brasileira de Sementes, v.30, n.3, p.71-78, 2008. http://www. scielo.br/scielo.php?pid=S0101-31222008000300010\&script $=$ sci abstract\&tlng-pt

ATAÍDE, G.M.; FLORES, A.V.; BORGES, E.E.L. Alterações fisiológicas e bioquímicas em sementes de Pterogyne nitens Tull. durante o envelhecimento artificial. Pesquisa Agropecuária Tropical, v.42, n. 1, p. 71-76, 2012. http://www.scielo.br/scielo. php?script $=$ sci arttext\&pid $=$ S1983-40632012000100010

BALEŠEVIĆ-TUBIĆ, S.; TATIĆ, M.; ĐORĐEVIĆ, V.; NIKOLIĆ, Z.; ĐUKIĆ, V. Seed viability of oil crops depending on storage conditions. Helia, v.33, n.52, p.153-160, 2010. http://www.doiserbia. nb.rs/img/doi/1018-1806/2010/1018-18061052153B.pdf

BRASIL. Ministério daAgricultura,Pecuária eAbastecimento. Regras para análise de sementes. Ministério da Agricultura, Pecuária e Abastecimento. Secretaria de Defesa Agropecuária. Brasília: MAPA/ACS, 2009. 395p. http://www.agricultura.gov.br/assuntos/ insumos-agropecuarios/arquivos-publicacoes-insumos/2946_ regras_analise_sementes.pdf/view

BORGES, E.E.L.; BORGES, R.C.G.; BUCKERIDGE, M.S. Alterações nas composições de carboidratos e de ácidos graxos em sementes de jacarandá-da-bahia osmocondicionadas. Revista Brasileira de Fisiologia Vegetal, v.12, n.1, p.10-16, 2002.http://www.scielo.br/scielo. php?script=sci_arttext\&pid=S0100-67622002000500011

CAMARGO, M.L.P.; MORI, E.S.; MELLO, E.J.; ODA, S.; LIMA, G.P.A. Atividade enzimática em plântulas de Eucalyptus grandis provenientes de sementes envelhecidas artificialmente e naturalmente. Ciência Florestal, v.10, n.2, p.113-122, 2000. http:// coral.ufsm.br/cienciaflorestal/artigos/v10n2/art9v10n2.pdf

CARVALHO, N.M.; NAKAGAWA, J. Sementes: ciência, tecnologia e produção. Jaboticabal: Funep, 2012. 588 p.

COELHO, S.V.B.; FIGUEIREDO, M.A.; CLEMENTE, A.C.S.; COELHO, L.F.S.; ROSA, S.D.V.F. Alterações fisiológicas e bioquímicas em sementes de café secas em sílica gel e soluções salinas saturadas. Pesquisa Agropecuária Brasileira, v.50, n.6, p.483-491, 2015. http:// www.scielo.br/pdf/pab/v50n6/0100-204X-pab-50-06-00483.pdf

CORTE, V.B.; BORGES, E.E.L.; LEITE, H.G.; LEITE, I.T.A. Qualidade fisiológica de sementes de Melanoxylon brauna envelhecidas natural e artificialmente. Scientia Florestalis, v.38, n.86, p.181-189, 2010. http:// www.ipef.br/publicacoes/scientia/nr86/cap06.pdf 
DELOUCHE, J.C. An accelerated aging technique for predicting relative storability of crimson clover and tall fescue seed lots. Agronomy Abstracts, v.40, n.1, p.40, 1965. http://ir.library.msstate. edu/bitstream/handle/11668/13316/F-4.pdf?sequence $=1$

DUSSERT, S.; COUTURON, E.; ENGELMANN, F.; JOET, T. Biologie de la conservation des semences de caféiers: aspects fondamentaux et consequences pratiques: une revue. Cahiers Agriculture, v.21, n.2, p.106-114, 2012. http://www.documentation. ird.fr/hor/fdi:010056109

ELLIS, R.H.; HONG, T.D.; ROBERTS, E.H. An intermediate category of seed storage behaviour? I. Coffee. Journal of Experimental Botany, v.41, n.230, p.1167-1174, 1990. https://www.jstor.org/ stable/23695125?seq=1\#page_scan_tab_contents

FANAN, S.; MEDINA, P.F.; LIMA, T.C; MARCOS-FILHO, J. Avaliação do vigor de sementes de trigo pelos testes de envelhecimento acelerado e de frio. Revista Brasileira de Sementes, v.28, p. 152-158, 2006. http://www.scielo.br/scielo.php?pid=S0101$31222006000200021 \&$ script $=$ sci_abstract\&tlng $=$ pt

FERREIRA, D.F. SISVAR: A computer statistical analysis system. Ciência e Agrotecnologia, Lavras, v.35, n.6, p.1039-1042, 2011. http:// www.scielo.br/scielo.php?pid=S1413-70542011000600001\&script $=$ sci arttext\&tlng $=\mathrm{pt}$

FREITAS, R.A.; DIAS, D.C.F.S.; OLIVEIRA, G.A.; DIAS, L.A.S.; JOSÉ, I.C. Mudanças fisiológicas e bioquímicas em sementes de algodão naturais e envelhecidas artificialmente. Seed Science and Technology, v.34, n.2, p.253-264, 2006. http://www.ingentaconnect. com/contentone/ista/sst/2006/00000034/00000002/art00001

GARCIA, C.; COELHO, C.M.M.; MARASCHIN, M.; OLIVEIRA, L.M. Conservação da viabilidade e vigor de sementes de Araucaria angustifolia (Bertol.) Kuntze durante o armazenamento. Ciência Florestal, v.24, n.4, p.857-867, 2014. http://www.scielo.br/scielo. php?pid=S1980-50982014000400857\&script=sci_abstract\&tlng $=$ pt

GONZÁlEZ, J.D.; FERNÁNDEZ, B.B.; CARREÑO, F.S. Influência de diferentes métodos de conservación em la germinación de semillas de palma areca (Dypsis lutescens, H. Wendel). Cultivos Tropicales, v.33, n.2, p.56-60, 2012. http://scielo.sld.cu/scielo. php?pid=S0258-59362012000200008\&script=sci_abstract

MARCOS-FILHO, J. Fisiologia de sementes de plantas cultivadas. Piracicaba: FEALQ. 2015. 495p.

MILOŠEVIC, M.; VUJAKOVIC, M.; KARAGIC, D. Vigour tests as indicators of seed viability. Genetika, v. 42, n. 1, p. 1-16, 2010. http:// www.doiserbia.nb.rs/img/doi/0534-0012/2010/0534-00121001103M.pdf

MORAES, C.E.; LOPES, J.C.; FARIAS, C.C.M.; MACIEL, K.S. Qualidade fisiológica de sementes de Tabernaemontana fuchsiaefolia A. DC em função do teste de envelhecimento acelerado. Ciência Florestal, v.26, n.1, p.213-223, 2016. http://www.scielo.br/scielo. php?script=sci_arttext\&pid=S1980-50982016000100213

OSSANI, P.C.; CIRILLO, M.A. MVar.pt: Análise multivariada (Brazilian Portuguese). 2016. https://cran.r-project.org/web/ packages/MVar.pt/index.html.
PEREIRA, M.D.; MARTINS FILHO, S.; LAVIOLA, B.G. Envelhecimento acelerado de sementes de pinhão-manso. Pesquisa Agropecuária Tropical, v.42, n.1, p.119-123, 2012. https://www. revistas.ufg.br/pat/article/view/12175

ROSA, S.D.V.F.; BRANDÃO JUNIOR, D.S.; VAN PINHO, E.V.R.; VEIGA, A.D.; SILVA, L.H.C. Effects of different drying rates on the physiological quality of Coffea canephora Pierre seeds. Brazilian Journal of Plant Physiology, v.17, n.2, p.199-205, 2005. http://www. scielo.br/scielo.php?pid=S1677-04202005000200002\&script $=$ sci_ arttext

REZENDE, M.L.; FERNANDES, L.P.S.; SILVA, A.M.R. Utilização da análise fatorial para determinar o potencial de crescimento econômico em uma região do Sudeste do Brasil. Economia e Desenvolvimento, v.26, n.19, p.1-18, 2007. http://w3.ufsm.br/depcie/ arquivos/artigo/5artigomarcelo.pdf

SANTOS, S.R.G.; PAULA, R.C. Teste de envelhecimento acelerado para avaliação do vigor de lotes de sementes de Sebastiania commersoniana (Baill.) Smith \& Downs (branquilho)-Euphorbiaceae. Revista do Instituto Florestal, v.19, n.1, p.1-12, 2007. http://www.ipef. br/publicacoes/scientia/nr81/cap01.pdf

SHIBATA, M.; COELHO, C.M.M.; OLIVEIRA, L.M.; GARCIA, C. Envelhecimento acelerado de sementes de ipê em condições controladas de armazenamento. Revista Brasileira de Sementes, v.34, n.2, p.247-254, 2012. http://www.scielo.br/scielo.php?pid=S010131222012000200009\&script=sci_arttext

SILVA, J.B.; LAZARINI, E.; SÁ, M.E. Comportamento de sementes de cultivares de soja, submetidas a diferentes períodos de envelhecimento acelerado. Bioscience Journal, v.26, n.5, p.755-762, 2010. http://www. seer.ufu.br/index.php/biosciencejournal/article/view/7187

SOUZA, J.R.P.; TAKAHASHI, L.S.A.; YOSHIDA,A.E.; GUIRAUD, M.C.; ROCHA, J.N. Tempo de armazenamento e temperatura na porcentagem e velocidade de germinação das sementes de camomila. Ciência Rural, v.37, n.4, p.982-986, 2007. http:/www.scielo.br/ scielo.php?script $=$ sci_arttext\&pid $=$ S0103-84782007000400010

SUNG, J.M.; JENG, T.L. Lipid peroxidation and peroxidescavenging enzymes associated with accelerated ageing of peanut seed. Physiologia Plantarum, v.91, p.51-55, 1994. http://onlinelibrary. wiley.com/doi/10.1111/j.1399-3054.1994.tb00658.x/abstract

TUNES, L.M.; TAVARE, L.C.; RUFINO, C.A.; VIEIRA, J.F.; ACUNHA, T.S.; BARROS, A.C.S.A.; MUNIZ, M.F.B. Accelerated aging of onion seeds (Allium cepa L.) submitted to saturated salt solution. Revista Colombiana de Ciências Hortícolas, v.5, n.2, p.244-250, 2011. http://www.scielo.org.co/scielo.php?script=sci_ arttext\&pid=S2011-21732011000200008

VIEIRA, A.R.; OLIVEIRA, J.A.; GUIMARÃES, R.M.; PEREIRA, C.E.; CARVALHO, F.E. Armazenamento de sementes de cafeeiro: ambientes e métodos de secagem. Revista Brasileira de Sementes, v.29, n.1,p.76-82, 2007.http://www.scielo.br/scielo.php?pid=S010131222007000100011\&script=sci_abstract\&tlng=pt 